\title{
DESAIN SISTEM KONTROL PENGGERAK MULA GENERATOR MAGNET PERMANEN PLTMH MENGGUNAKAN PLANETERY GEAR
}

\author{
${ }^{1}$ Rizki Pratama Putra, ${ }^{2}$ Samsurizal, ${ }^{3}$ Novi Gusti Pahiyanti \\ 1,2,3 Departemen Teknik Elektro, Sekolah Tinggi Teknik PLN \\ ${ }^{1}$ rizki@ sttpln.ac.id, ${ }^{2}$ samsurizal@ @stpln.ac.id, ${ }^{3}$ novi.gusti@sttpln.ac.id
}

\begin{abstract}
Voltage and frequency stability of a micro hydro power plant requires a simple, reliable and efficient control system. This study aims to design a control system using planetary gear which is known to provide fast speed adjustments to respond to the changing rate of water flow. In this study the system design will be created using matlab simulink. The system will then be simulated with various turbine rotation conditions to see the reliability and stability of the frequency and voltage produced by the permanent magnet generator used in micro hydro power plant. The results obtained are the control system seems can stabilize the generator rotor rotation so that the resulting voltage frequency remains constant even though the input load and water flow rate are dynamic. From the simulation results it is also found that the efficiency of the control system is directly proportional to the difference in mechanical input and electric power output of the system.
\end{abstract}

Keywords : Micro Hydro Power Plant, Planetary Gear, Frequency Control, Stability, Efficiency

\begin{abstract}
ABSTRAK
Keandalan dan stabilitas tegangan dan frekuensi dari suatu PLTMH (Pembangkit Listrik Tenaga Mikro Hidro) membutuhkan suatu sistem kontrol yang sederhana, handal dan efisien. Penelitian ini bertujuan untuk merancang suatu sistem kendali menggunakan planetary gear yang dikenal dapat memberikan penyesuaian kecepatan yang cepat guna merespon laju debit air yang berubahubah. Dalam penelitian ini desain sistem akan dibuat menggunakan matlab simulink. Sistem kemudian akan disimulasikan dengan berbagai kondisi putaran turbin yang berubah-ubah untuk melihat keandalan dan kestabilan frekuensi dan tegangan yang dihasilkan oleh generator PLTMH magnet permanen. Hasil yang diperoleh adalah sistem pengontrolan terlihat dapat menstabilkan putaran rotor generator sehingga frekuensi tegangan yang dihasilkan tetap konstan meskipun beban dan debit air masukan dinamis. Dari hasil simulasi juga didapatkan bahwa efisiensi pengontrolan berbanding lurus dengan selisih daya mekanis dan elektris dari sistem.
\end{abstract}

Kata kunci: PLTMH, Planetary Gear, Kontrol Frekuensi, Stabilitas, Efisiensi 


\section{PENDAHULUAN}

\subsection{Latar Belakang Masalah}

Stabilitas dan keandalan dari suatu sistem pembangkitan tenaga listrik merupakan suatu hal yang menjadi pokok pembahasan dalam perancangan suatu pembangkit tenaga listrik. Suatu sistem pembangkitan yang baik tentunya harus mampu menyediakan daya listrik yang stabil dan handal sepanjang waktu (Kundur 1994). Pada pembangkit listrik tenaga mikro hidro, keandalan dan kestabilan tegangan dan frekuensi sangat bergantung dari laju debit air yang memutar turbin generator. Disamping itu kondisi beban yang fluktuatif akan memberikan pengaruh pada kestabilan tegangan dan frekuensi dari pembangkit PLTMH tersebut.

Untuk menjaga kestabilan tegangan dan frekuensi dari suatu pembangkit listrik, pengontrolan dapat dilakukan pada sisi penggerak mula dan sisi beban. Untuk PLTMH sendiri dimana laju debit air sangat variatif maka pengontrolan pada sisi penggerak mula sangat penting untuk diperhatikan dan dikaji lebih dalam untuk menghasilkan suatu sistem kontrol yang handal dan dapat memberikan kestabilan yang dibutuhkan.

Teknik pengontrolan yang umum dilakukan saat ini adalah dengan mengontrol bukaan katup pipa pesat dengan governor untuk mengatur putaran air. Teknik ini telah terbukti handal untuk pembangkit listrik skala besar yang memiliki reservoir yang menghasilkan laju debit air yang konstan. Namun untuk pembangkit mikro hidro skala kecil yang tidak memiliki reservoir yang baik, teknik pengontrolan governor tidak bisa memberikan kestabilan tegangan dan frekuensi yang baik sebab laju debit air sangat variatif (Ogata 2002).

Oleh sebab itu dalam penelitian ini akan dikaji suatu teknik pengontrolan putaran rotor generator menggunakan planetary gear yang diharapkan mampu memberikan putaran rotor sekaligus frekuensi tegangan yang konstan meskipun input debit air berubah-ubah.

\subsection{Tujuan Penelitian}

Adapun tujuan yang hendak dicapai dalam penelitian ini adalah:

1. Merancang suatu sistem kontrol penggerak mula generator daya kecil dengan mengimplementasikan penggunaan planetary gear

2. Mensimulasikan sistem kontrol tersebut diatas untuk mengetahui kestabilan dan keandalan generator PLTMH (mikro hidro)

\section{Metodologi Penelitian}

Alur kerja penelitian dapat dilihat pada bagan di bawah ini:

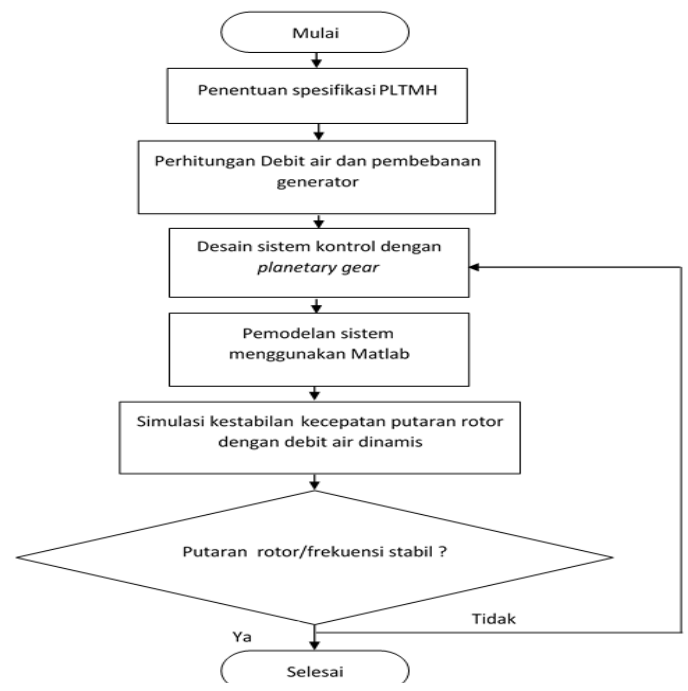

Gambar 1. Diagram alir penelitian 
PLTMH yang dikaji pada penelitian ini adalah PLTMH yang menggunakan aliran air run-ofriver atau menggunakan saluran air kecil hingga sedang dengan debit air rendah hingga sedang. Penentuan spesifikasi PLTMH merupakan langkah awal untuk mendesain sistem pengontrolan yang akan dilakukan.

Parameter-parameter yang mempengaruhi desain PLTMH akan ditentukan terlebih dahulu sebelum dilakukan pemodelan sistem PLTMH (Nasir 2014).

Nilai debit air maksimum dan minimum diambil dari data penelitian yang dilakukan oleh Subekti (2010) di Provinsi Nangroe Aceh Darussalam. Dari rentang nilai ini kemudian debit air akan divariasikan dalam simulasi.

Untuk nilai pembebanan generator, nilai maksimumnya diambil dari rating generator dan nilai minimumnya adalah kondisi tanpa beban.

Setelah mengetahui kondisi debit air dan pembebanan selanjutnya adalah mendesain sistem pengontrolan dengan menggunakan planetary gear. Data perubahan debit air dan pembebanan diperlukan dalam mendesain planetary gear tersebut. Untuk efisiensi kerja dari planetary gear, mengenai jumlah roda gigi dan rasio antara roda gigi juga turut dipertimbangkan agar pengontrolan berjalan efisien (Adam Lundin 2010)

Untuk rasio roda gigi planetary gear akan dicari dengan menggunakan persamaan berikut (Kahraman 1994):

$$
\tau_{s}=-\tau_{c} \frac{N_{s}}{N_{r}+N_{s}} \ldots \ldots \ldots
$$

Setelah parameter-parameter terkait telah didapatkan, PLTMH akan dimodelkan menggunakan Matlab simulink untuk mensimulasikan sistem secara keseluruhan. Pada proses simulasi, debit air dan beban generator dibuat dinamis sehingga frekuensi sistem tanpa pengontrolan akan berubah-ubah sedangkan dengan pengontrolan diharapkan frekuensi tegangan pada beban stabil. Apabila kestabilan frekuensi telah tercapai berarti sistem pengontrolan telah berhasil namun jika sistem masih belum stabil maka perlu pengaturan atau perbaikan pada desain gearbox.

\section{Hasil dan Analisa}

\subsection{Simulasi PLTMH Tanpa Aplikasi Pengontrolan}

Pada bagian ini simulasi dijalankan dengan nilai torka sebesar $20 \mathrm{Nm}$, nilai pembebanan dibuat konstan dengan memberi beban resistif sebesar $8.5 \mathrm{ohm}$. PLTMH dijalankan tanpa aplikasi pengontrolan. Adapun hasil simulasi dapat dilihat pada gambar dibawah ini:

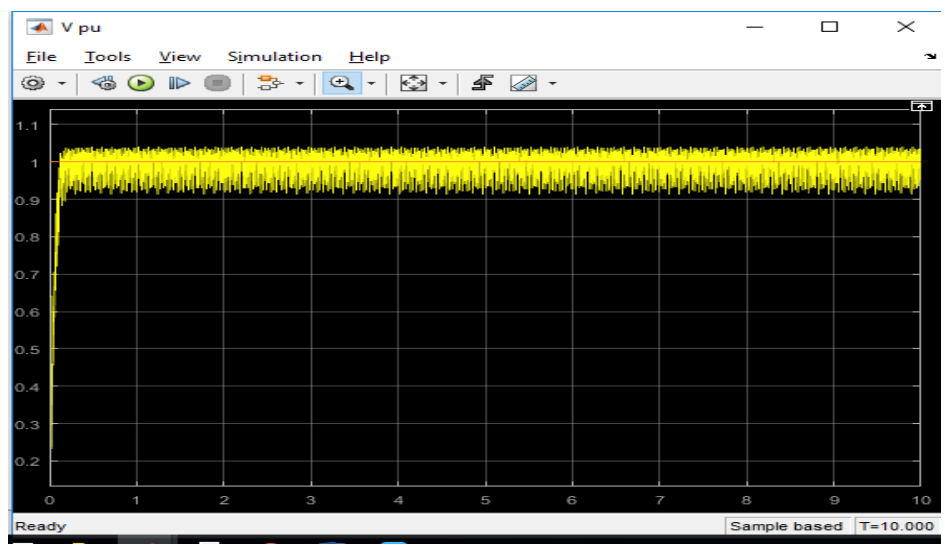

Gambar 2. Grafik Hubungan tegangan output (pu) terhadap torka mekanik dalam kondisi tanpa pengontrolan 
Dari gambar 2 dapat dilihat bahwa tegangan output dari generator berosilasi selama simulasi dijalankan. Ini dapat disebabkan oleh frekuensi putaran generator yang tidak stabil. Adapun plot putaran turbin dapat dilihat pada gambar 3.

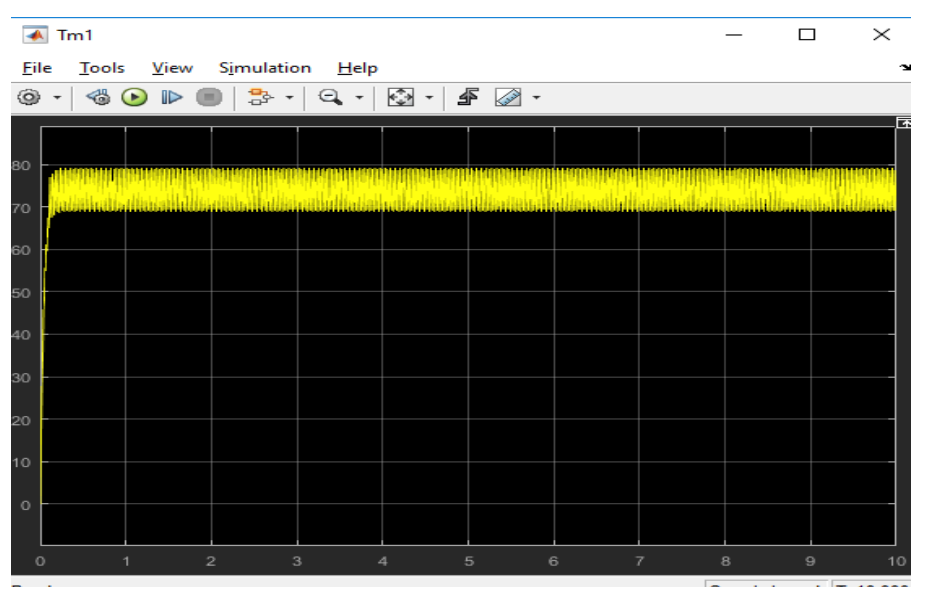

Gambar 3. Grafik perubahan putaran rotor generator selama simulasi

Dari gambar 3 terlihat bahwa putaran rotor terlihat berosilasi, yang menyebabkan frekuensi tegangan generator ikut berosilasi. Ini bisa saja terjadi sebab tidak ada yang mengontrol atau menstabilkan putaran rotor generator. besar kecepatan rotor generator bergantung dari persamaan dibawah ini.

$$
J \frac{d \omega}{d t}=J * \alpha=\left(T_{m}-T_{e}-K_{g} * \omega_{g}-K_{t} * \omega_{t}\right) \ldots \ldots \ldots(2)
$$

Pada persamaan tersebut torka elektrik $T_{e}$ berosilasi setiap waktu sebab menurut persamaan torka dibawah ini:

$$
\tau_{e}=1.5 p\left(\lambda i_{d}+\left(L_{d}-L_{q}\right) i_{d} i_{q}\right.
$$

Torka elektrik $\tau_{e}$ bergantung pada besarnya $i_{d} i_{q}$ yang merupakan fungsi sinusoidal. Ketika torka elektrik tidak sama dengan torka mekanik maka akan terjadi percepatan atau perlambatan putaran rotor. Oleh karena itu osilasi putaran turbin akan terjadi yang menyebabkan ketidakstabilan frekuensi tegangan generator.

\subsection{Simulasi PLTMH Dalam Keadaan Beban Konstan Dengan Pengontrolan}

Pada bagian ini simulasi dijalankan dengan nilai torka sebesar $20 \mathrm{Nm}$, nilai pembebanan dibuat konstant dengan memberi beban resistif sebesar $8.5 \mathrm{ohm}$. Pada tahap ini simulasi dijalankan menggunakan pengontrolan menggunakan gearbox. Adapun hasil simulasi dapat dilihat pada gambar dibawah ini: 


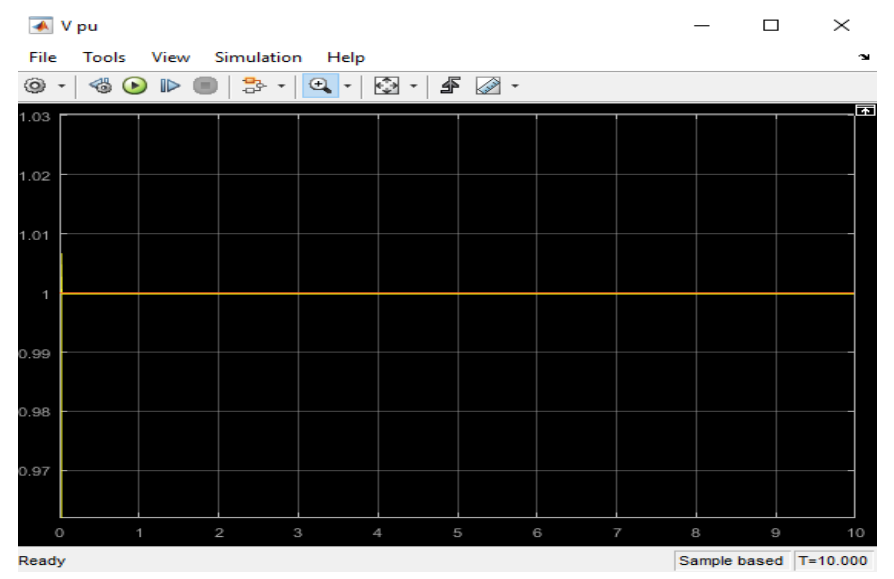

Gambar 4. Grafik perubahan tegangan output terhadap perubahan beban dan dengan torka input konstan.

Dari grafik diatas dapat dilihat bahwa nilai tegangan nominal dari generator tetap konstan, dengan pembebanan dan torka mekanik yang konstan juga. Secara teori jika torka mekanik lebih besar dari torka elektrik ditambah dengan rugi-rugi torka pada sistem pembangkit maka akan terjadi percepatan putaran pada poros turbin-generator, begitupun sebaliknya. Hal ini dapat dilihat kembali pada persamaan (2).

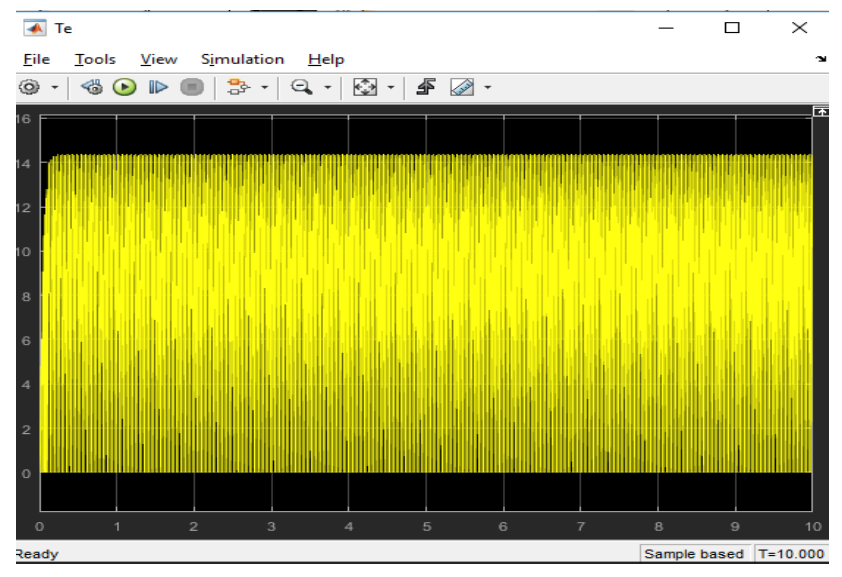

Gambar 5. Plot torka elektrik terhadap waktu

Pada hasil simulasi, sebenarnya terjadi akselerasi pada rotor turbin. Namun akselerasi tersebut besarnya tergantung dari torka elektrik dari generator. pada grafik torka diatas terlihat torka elektrik berosilasi, ini wajar saja karena berdasarkan persamaan torka dari generator yaitu pada persamaan (2), $i_{d}$ dan $i_{q}$ adalah fungsi sinusoidal sehingga torka juga akan berubah-ubah tergantung waktu. Oleh karena torka elektrik dinamis, percepatan dari rotor turbin akan terlihat dinamis. Ketika percepatan bernilai positif yaitu ketika torka mekanik lebih besar dari torka elektrik, maka akan terjadi kenaikan kecepatan rotor dan ketika torka elektrik lebih besar dari torka mekanik maka akan terjadi perlambatan kecepatan yang menurunkan kecepatan rotor.

Percepatan dan perlambatan tersebut berlangsung sangat cepat dan konsisten sesuai fungsi sinusoidal dari arus beban. Akibatnya putaran generator selalu terlihat konstan begitupun dengan frekuensi tegangan generator.

Putaran rotor generator akan selalu konstan karena pada planetary gearbox terjadi penyesuaian putaran roda gigi carrier yang merupakan output planetary gearbox yang terhubung langsung dengan poros generator. Adapun putaran roda-roda gigi dari planetary gearbox dapat dilihat pada gambar dibawah ini: 


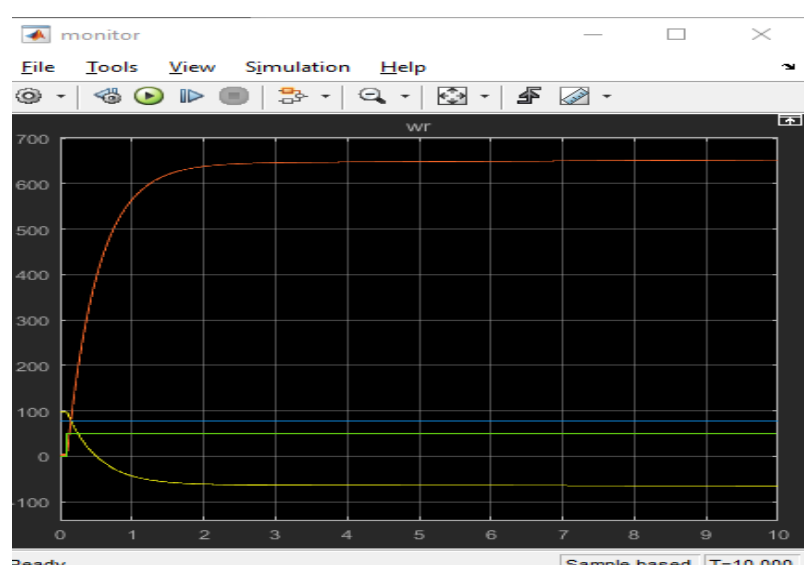

Gambar 6. Grafik Hubungan kecepatan sudut dari roda gigi cincin $\omega_{r}$, matahari $\omega_{s}$, roda gigi pembawa $\omega_{c}$, dan frekuensi generator

Pada gambar diatas dapat dilihat bahwa putaran roda gigi matahari $\omega_{s}$ meningkat secara exponensial. untuk menjaga putaran roda gigi carrier $\omega_{c}$ yang terhubung dengan generator tetap konstan, roda gigi cincin $\omega_{r}$ melakukan putaran penyesuaian sehingga putaran roda gigi pembawa dan frekuensi tegangan generator tetap konstan.

Penyesuaian putaran dalam praktek di lapangan dibantu menggunakan motor dc, sehingga semakin tinggi selisih torka mekanik dan elektrik maka putaran penyesuaian akan semakin besar yang menyebabkan efisiensi pengontrolan menjadi berkurang sebab diperlukan energi listrik untuk memutar motor penggerak tersebut.

\section{Efek GGl lawan dalam kondisi berbeban}

Simulasi dijalankan dengan menginput nilai torka sebesar $20 \mathrm{Nm}$, dengan nilai beban pembebanan dinamis membetuk slope negative mulai dengan nilai maksimum $8.5 \mathrm{ohm}$ dan nilai minimum $6.5 \mathrm{ohm}$. Nilai pembebanan dibuat dinamis untuk melihat bagaimana perubahan tegangan output apabila beban dibuat dinamis dan torka input dibuat konstan. Adapun hasil simulasi dapat dilihat pada gambar 7 .

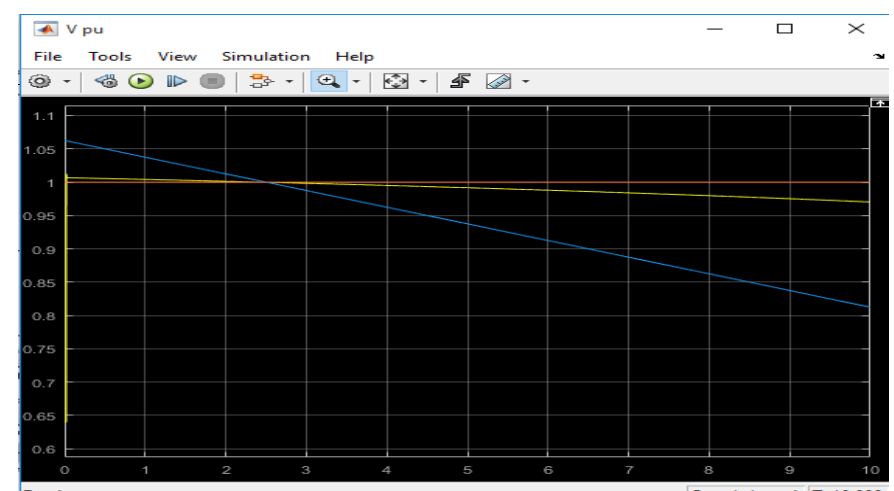

Gambar 7. Grafik perubahan tegangan output terhadap perubahan beban dan dengan torka input konstan.

Dari gambar diatas dapat dilihat bahwa tegangan output dari generator berbanding terbalik dengan nilai pembebanan. Apabila beban naik yang ditandai dengan mengecilnya nilai resistansi, maka nilai tegangan output generator menjadi turun.

Apabila nilai pembebanan naik maka arus yang mengalir pada stator generator dan pada beban akan naik. Ini akan menimbulkan GGL balik yang akan melawan medan rotor sehingga GGL yang diinduksikan oleh rotor ke stator menjadi berkurang. Berkurangnya nilai medan resultan ini tidak 
dapat dikompensasi oleh magnet permanen sebab magnet permanen pada rotor generator tersebut memiliki nilai flux magnetik yang konstan, berbeda halnya dengan generator dengan penguatan terpisah dimana nilai fluks magnetik resultan dapat disesuaikan melalui pengaturan arus eksitasi kumparan rotor sehingga fluks magnetik rotor tetap pada nilai nominalnya. Hal ini juga dapat dilihat menurut persamaan di bawah ini:

$$
e_{a}=\frac{d \psi_{a}}{d t}-R_{a} I_{a}
$$

Dari persamaan 4 dapat dilihat bahwa nilai tegangan output generator $e_{a}$ berbanding lurus dengan kuat medan rotor juga berbanding lurus dengan laju perubahan medan atau besar putaran rotor $\frac{d \psi_{a}}{d t}$ dalam hal ini medan magnet yang dihasilkan oleh magnet permanen pada rotor. Dari persamaan juga dapat dilihat bahwa semakin besar nilai arus beban $I_{a}$ atau arus yang mengalir pada stator maka nilai tegangan pada terminal stator akan semakin kecil.

\subsection{Simulasi PLTMH Dengan Beban Konstan Dan Debit Air Dinamis Dengan Pengontrolan}

Pada operasi PLTMH, setelah rotor generator dikopel dengan poros turbin, beban tidak langsung disambungkan ke generator. Sebelum disambung ke beban, putaran rotor generator harus mencapai nilai yang ditetapkan yaitu $78.4 \mathrm{rad} / \mathrm{s}$ sehingga frekuensi tegangan output adalah sekitar $50 \mathrm{~Hz}$. Oleh karena debit air yang disimulasikan memiliki nilai yang berubah-ubah sedangkan putaran rotor yang diinginkan adalah konstan maka terlebih dahulu disimulasikan bagaimana sistem pengaturan kecepatan yang dibuat dapat menstabilkan putaran rotor generator dalam keadaan beban konstan. Adapun data perubahan debit air di lapangan secara real time tidak tersedia namun data debit air efektif diketahui. Oleh karena itu diambil 4 macam fungsi perubahan debit air/torka air yang dianggap mewakili peruabah debit air dari kondisi sebenarnya. Adapun, hasil simulasi dapat dilihat pada gambar di bawah ini :

Hubungan torka penggerak mula dan putaran rotor generator dengan beban konstan:

\section{Torka penggerak mula fungsi sawtooth}

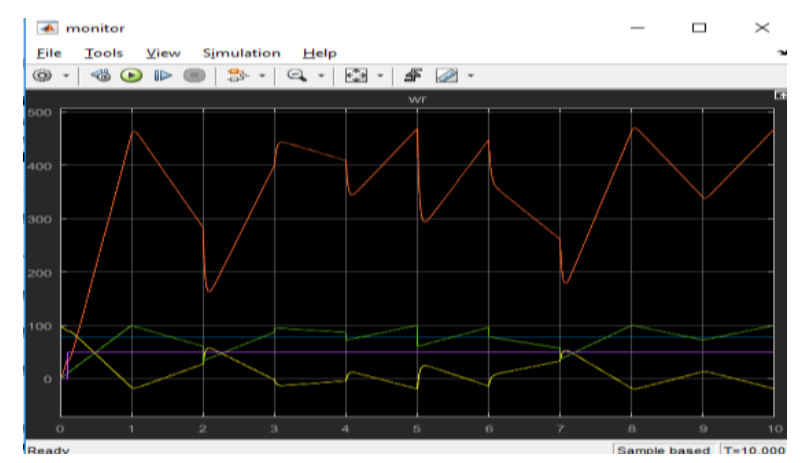

Gambar 8. Plot $\omega_{\text {generator }}, \omega_{\text {ring }}, \omega_{\text {turbin }}$ terhadap perubahan torka mekanik penggerak mula $\tau_{m}$ fungsi sawtooth 


\section{Torka penggerak mula fungsi sinusoidal}

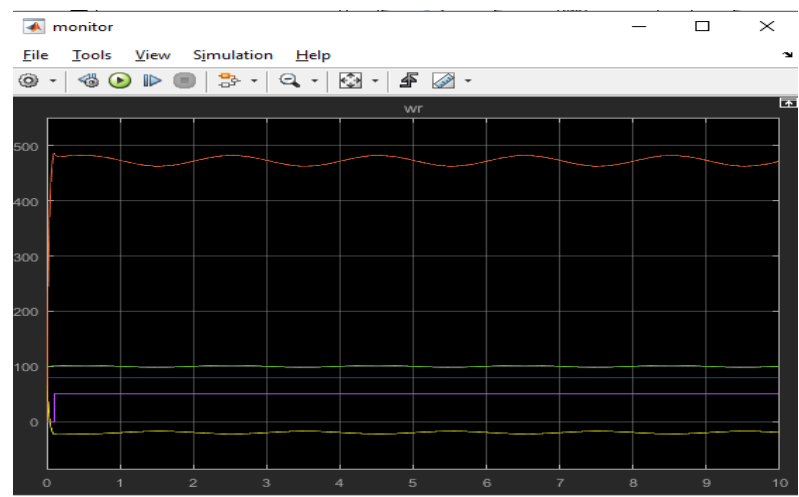

Gambar 9. Plot $\omega_{\text {generator }}, \omega_{\text {ring }}, \omega_{\text {turbin }}$

$f_{\text {tegangan }}$, terhadap perubahan torka mekanik penggerak mula $\tau_{m}$ fungsi sinusoidal

\section{Torka penggerak mula fungsi impuls/pulsa}

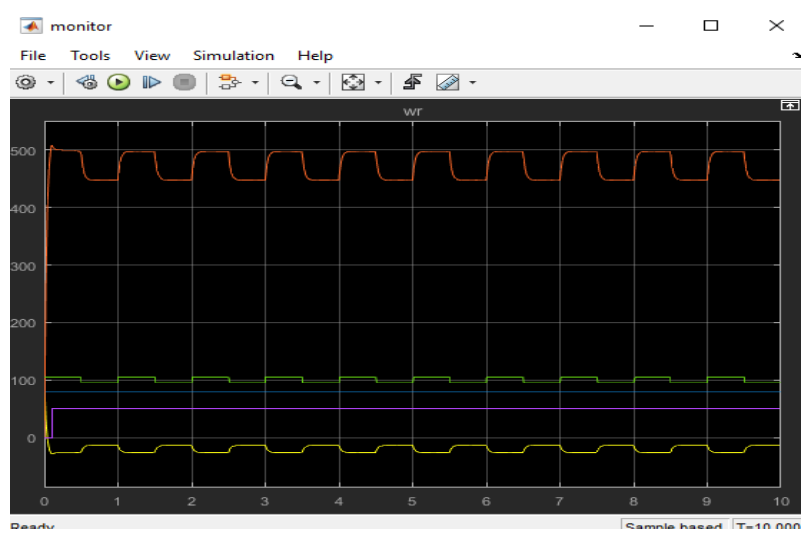

Gambar 10. Plot $\omega_{\text {generator }}, \omega_{\text {ring }}, \omega_{\text {turbin }}$,

$f_{\text {tegangan }}$, terhadap perubahan torka mekanik penggerak mula $\tau_{m}$ fungsi pulsa

\section{Torka penggerak mula fungsi Gaussian random}

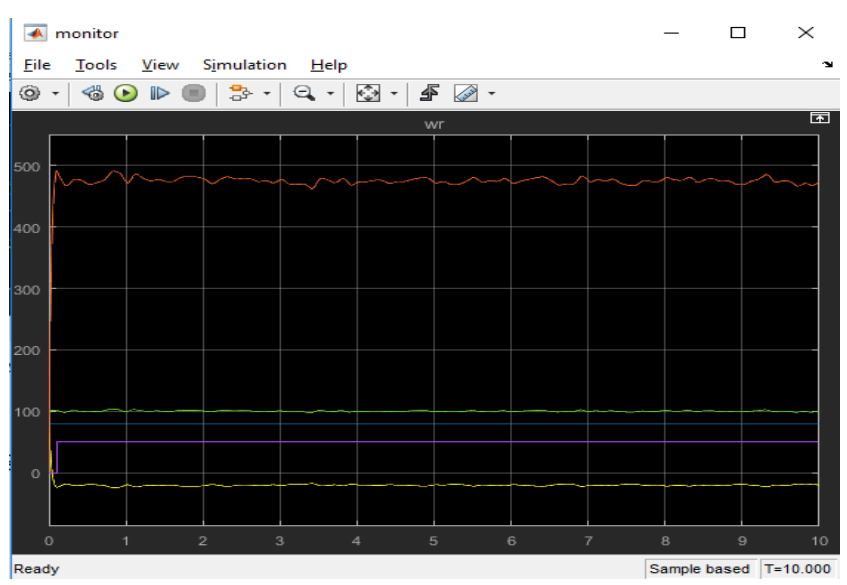

Gambar 11. Plot $\omega_{\text {generator }}, \omega_{\text {ring }}, \omega_{\text {turbin }}$,

$f_{\text {tegangan }}$, terhadap perubahan torka mekanik penggerak mula $\tau_{m}$ fungsi Gaussian random 
Dari gambar 11 secara umum dapat dilihat bahwa meskipun torka yang dihasilkan oleh debit air berubah-ubah, dalam keadaan beban konstan putaran generator tetap stabil. Dari simulasi diatas dapat dilihat bahwa jika perubahan input debit air menyerupai fungsi ramp, impuls, atau step, putaran rotor dapat dikembalikan dalam sesaat. Karena sistem penggerak mula tidak menggunakan governor, debit air terus memutar turbin dengan torka $\tau_{m}$ dan dengan percepatan $\alpha_{m}$. Ketika beban dimasukkan ke sistem, torka elektrik $\tau_{e}$ bersama-sama dengan torka damping generator $\tau_{d g}$, turbin $\tau_{d t}$ akan meredam torka mekanik sehingga percepatan turbin menjadi kecil dan akan sama dengan 0 jika selisih torka mekanik dan torka lainnya sama dengan 0 juga, pada saat tersebut kecepatan sudut rotor generator akan stabil.

Pada bagian ini simulasi dijalankan dengan nilai torka sebesar $20 \mathrm{Nm}$, nilai pembebanan dibuat konstant dengan memberi beban resistif sebesar $8.5 \mathrm{ohm}$. PLTMH dijalankan tanpa aplikasi pengontrolan. Adapun hasil simulasi dapat dilihat pada gambar dibawah ini :

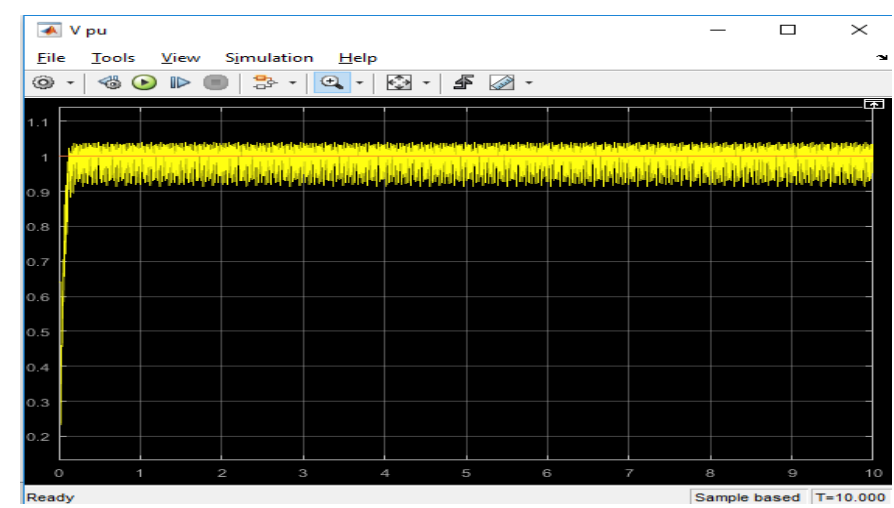

Gambar 12. Grafik Hubungan tegangan output (pu) terhadap torka mekanik dalam kondisi tanpa pengontrolan

Dari gambar 12 dapat dilihat bahwa tegangan output dari generator berosilasi selama simulasi dijalankan. Ini dapat disebabkan oleh frekuensi putaran generator yang tidak stabil. Adapun plot putaran turbin dapat dilihat pada gambar 13.

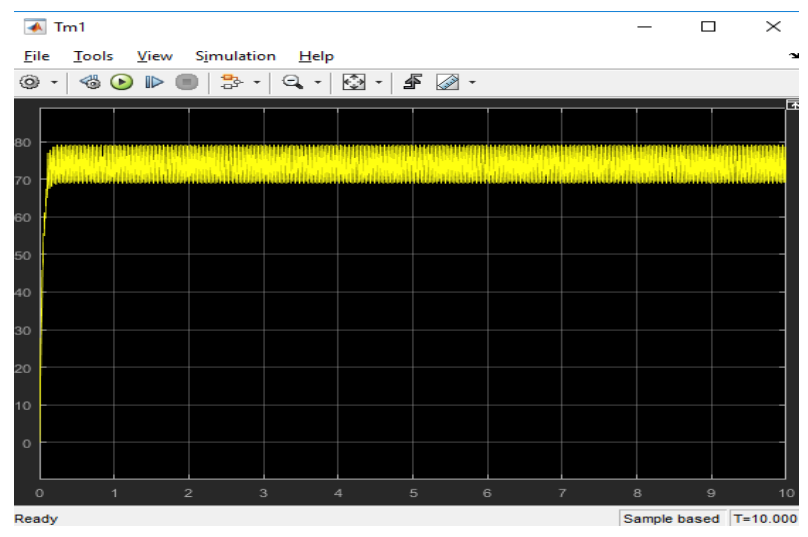

Gambar 13. Grafik perubahan putaran rotor generator selama simulasi

Dari gambar 13 terlihat bahwa putaran rotor terlihat berosilasi, yang menyebabkan frekuensi tegangan generator ikut berosilasi. Ini bisa saja terjadi sebab tidak ada yang mengontrol atau menstabilkan putaran rotor generator. besar kecepatan rotor generator bergantung dari persamaan dibawah ini (Ogata 2002). 


$$
J \frac{d \omega}{d t}=J * \alpha=\left(T_{m}-T_{e}-K_{g} * \omega_{g}-K_{t} * \omega_{t}\right) \ldots
$$

Pada persamaan tersebut torka elektrik $\square_{\square}$ berosilasi setiap waktu sebab menurut persamaan torka dibawah ini:

$$
\tau_{e}=1.5 p\left(\lambda i_{d}+\left(L_{d}-L_{q}\right) i_{d} i_{q} \ldots \ldots \ldots \ldots \ldots(6)\right.
$$

Torka elektrik $\tau_{e}$ bergantung pada besarnya $i_{d} i_{q}$ yang merupakan fungsi sinusoidal. Ketika torka elektrik tidak sama dengan torka mekanik maka akan terjadi percepatan atau perlambatan putaran rotor. Oleh karena itu osilasi putaran turbin akan terjadi yang menyebabkan ketidakstabilan frekuensi tegangan generator.

\section{KESIMPULAN DAN SARAN}

Adapun kesimpulan yang dapat diambil dari penelitian yang telah kami lakukan diantaranya sebagai berikut:

1. Pada simulasi tanpa adanya pengontrolan dengan debit air yang berubah-ubah dan beban konstan didapatkan bahwa frekuensi tegangan generator menjadi tidak konstan, ini disebabkan oleh frekuensi tegangan yang mengikuti putaran rotor generator, apabila debit air naik maka akan terjadi percepatan pada rotor generator yang mengakibatkan putaran menjadi naik begitupun sebaliknya.

2. Dalam simulasi dengan debit air konstan dan beban berubah-ubah, didapatkan bahwa perubahan beban mengakibatkan perubahan torka elektrik yang harus diimbangi dengan perubahan suplai torka mekanik untuk menghasilkan putaran rotor generator yang stabil sehingga menghasilkan frekuensi tegangan yang kontan/stabil.

3. Perubahan beban menghasilkan perubahan tegangan output meskipun putaran rotor generator dijaga konstan. Ini disebabkan karena adanya ggl lawan yang mengurangi fluks resultan dari magnet permanen sehingga tegangan yang diinduksikan ke stator menjadi berkurang.

4. Penggunaan planetary gearbox pada sistem penggerak mula dari PLTMH dalam simulasi dapat menstabilkan putaran rotor generator, dimana apabila terjadi perubahan torka mekanik dari turbin yang mengakibatkan perubahan akselerasi rotor turbin maka roda gigi cincin pada plateray gearbox akan memberikan putaran penyesuaian sehingga roda gigi matahari yang merupakan output dari planetary gearbox yang terkopel dengan rotor generator akan menghasilkan putaran yang selalu konstan.

5. Dari hasil simulasi menggunakan perubahan debit yang bervariasi, tidak ditemukan overshoot ataupun rising time yang lama dari putaran output planetary gear. Ini bisa disebabkan karena respon rangkaian elektrik pengendali motor listrik dari roda gigi cincin dianggap tidak memiliki waktu delay sehingga sinyal feedback dianggap dapat langsung dieksekusi dan diteruskan ke motor penggerak roda gigi cincin.

6. Putaran penyesuaian dari roda gigi cincin memerlukan energi dari motor penggerak sehingga semakin jauh perbedaan daya mekanik dan daya elektrik ditambah rugi-rugi daya maka efisiensi pengontrolan akan semakin berkurang

Adapun saran untuk penelitian ini kedepannya adalah:

1. Diharapkan penelitian ini dapat dijadikan salah satu materi bahan praktikum sistem Kontrol.

2. Diharapkan agar purwarupa dari desain pengontrolan ini dapat dibuat kemudian diterapkan pada kondisi nyata. 


\section{DAFTAR PUSTAKA}

- Jurnal

Subekti, Arief R. (2012). "Survey Potensi Pembangkit Listrik Tenaga Mikro Hidro di Kuta Malaka Kabupaten Aceh Besar Propinsi Nanggroe Aceh Darussalam." Journal of Mechatronics, Electrical Power, and Vehicular Technology 1.1 : 5-12.

Nasir, Bilal Abdullah. (2014). Design considerations of micro-hydro-electric power plant. Energy Procedia 50 : 19-29.

Kahraman, A. (1994). Planetary gear train dynamics. Journal of Mechanical design 116.3 : 713720.

Gustavsson Mårdestam, P., \& Lundin, A. (2010). Efficiency Analysis of a Planetary Gearbox :

\section{- Buku}

Kundur, Prabha, Neal J. Balu, and Mark G. Lauby. (1994). Power system stability and control. Vol. 7. New York: McGraw-Hill. ISBN : 9780070635159.

Ogata, Katsuhiko, and Yanjuan Yang. (2002). Modern control engineering. Vol. 4. India: Prentice hall. ISBN: 0136156738 